Scientia Marina 71(1)

March 2007, 137-144, Barcelona (Spain)

ISSN: 0214-8358

\title{
Notes on the biology of the bigeye scad, Selar crumenophthalmus (Carangidae) around Reunion Island, southwest Indian Ocean
}

\author{
DAVID ROOS ${ }^{1}$, OLIVIER ROUX ${ }^{2}$ and FRANÇOIS CONAND ${ }^{3}$ \\ ${ }^{1}$ Institut Français de Recherche pour 1'Exploitation de la Mer, BP171, Av. Jean Monet 34203 Sète Cedex, France. \\ E-mail: David.Roos@ifremer.fr \\ ${ }^{2}$ Otolithe - 1bis rue des Lavandes, 34970 Lattes, France. \\ ${ }^{3}$ Laboratoire d'écologie marine, Université de La Réunion, 97715 St-Denis, France.
}

\begin{abstract}
SUMMARY: The main characteristics of the biology of bigeye scad were studied from commercial fishery catches around Reunion Island. Biometric relationships were calculated. The monitoring of size distribution, aggregated by month, allowed us to estimate the theoretical growth equation using the ELEFAN software. The von Bertalanffy growth parameters were adjusted with a seasonal modulation: $\mathrm{L}_{\infty}=265 \mathrm{~mm} ; \mathrm{K}=1.64$ year-1 $^{-1} \mathrm{c}=0.068 ; \varphi=0.38$. The growth of the cohort was quite high during the austral summer (November-April) and decreased during the austral winter (May-October). The arrival of a new cohort with homogeneous small sizes $(65$ to $90 \mathrm{~mm}$ ) in the fishery in November coincided with the disappearance of large individuals. A feature of the reproductive biology was that the sex ratio remained constant month by month and that there was no predominance of male or female even in the larger size classes. Fish were mature by April and the proportion of mature fish progressively increased until November, when the gonad-indices were the highest. The size at first maturity (L50) was reached at $215 \mathrm{~mm}$ (fork length). The largest specimens observed were $255 \mathrm{~mm}$ long (fork length). After reproduction, massive mortality occurred and few individuals survived.
\end{abstract}

Keywords: Carangidae, Selar crumenophthalmus, reproduction, growth, Reunion Island, Indian Ocean.

RESUMEN: Notas SOBRE LA BIOLOGÍA DEl BIGEYE SCAD, SELAR CRUMENOPHTHALMUS (CARANGIDAE), EN LA ISLA ReUNIÓN, SUROESTE DEL OCÉANO ÍNDICO. - Las principales características de la biología del Selar crumenophtalmus fueron estudiadas en la isla Reunión utilizando los desembarques comerciales. Se calcularon las relaciones biométricas. El seguimiento de la distribución mensual de la longitud nos permitió estimar la ecuación de la curva de crecimiento teórico, utilizando el programa ELEFAN. Los parámetros del modelo de crecimiento de Von Bertalanffy fueron ajustados con una modulación estacional: $\mathrm{L}_{\infty}=265 \mathrm{~mm} ; \mathrm{K}=1.64$ year $^{-1} ; \mathrm{c}=0.068 ; \varphi=0.38$. La tasa de crecimiento de las cohortes fue muy rápida durante el verano austral (noviembre-abril) y disminuyó durante el invierno (mayo-octubre). La llegada de una nueva cohorte de pequeños individuos de longitud homogénea $(65-90 \mathrm{~mm}$ ) a la pesquería en noviembre, coincidió con la desaparición de los individuos más grandes. La relación de sexos permaneció constante a lo largo del año y no se vio una superioridad numérica de los machos o de las hembras, ni en las clases de tamaño más grandes. Los primeros peces maduros fueron observados desde el mes de abril y la proporción creció hasta noviembre (índice gonadosomático máximo). La talla de primera madurez (L50) fue alcanzada a los $215 \mathrm{~mm}$ (longitud furca, LF). Los peces más grandes observados midieron $255 \mathrm{~mm}$ (LF). Después de la reproducción, ocurrió una mortalidad masiva y pocos individuos sobrevivieron.

Palabras clave: Carangidae, Selar crumenophthalmus, reproducción, crecimiento, isla Reunión, Océano Índico.

\section{INTRODUCTION}

Bigeye scad or atule (Selar crumenophthalmus, Bloch, 1973, Carangidae) is a species of great value to the small-scale fisheries of Reunion Island (Fig. 1). This small pelagic fish is caught in coastal waters all around the island, and is especially abundant in the northwestern coastal waters. Small pelagic species 
are important for subsistence and small commercial fisheries. On average, more than $68 \mathrm{t}$ (with a coefficient of variation of $36 \%$ ) of bigeye scads are harvested every year and represent the most important species in the small pelagic catches of Reunion Island (Roos et al., 1998). Bigeye scads are consumed fresh and also used as one of the most common live baits for tuna and other large pelagic fishes caught in association with fish-aggregating devices (FADs) (Biais and Taquet, 1992; Roos et al., 2000).

This species is caught by beach-seine and handline on sandy and rocky bottoms less than $80 \mathrm{~m}$ deep (Biais and Taquet, 1992). The beach-seine is mainly used in Saint-Paul Bay (Fig. 1) and occasionally around the main ports of the island. The dimensions of the seine depend on the size of the shoals spotted from the beach and/or the size of the fish. It can be up to $800 \mathrm{~m}$ long and consists of 14 to $20 \mathrm{~mm}$ wide mesh net sheets. The seine is set using two to three small fishing boats. The shoal is encircled and the net is drawn to the beach by fishermen. The catch is generally less than a metric ton although it can occasionally reach 2 to $15 \mathrm{t}$.

Handline fishing is practised during the night. Small pelagics are attracted to the boat by a light spot generated by an oil or electric lamp situated on the side of the boat. The line used is made of monofilament nylon $(\Phi 40 / 100)$ with a light sinker $(200 \mathrm{~g})$ at the end, and is equipped with 6 to 8 hooks, set about $30 \mathrm{~cm}$ apart. The best yields are obtained during moonless and new moon nights, when attraction by lights is most effective. This technique is practised very close to the coast, in quite shallow waters $(10$ to $80 \mathrm{~m})$ and mainly in bays.

Seasonal variability of catches and the repeated conflicts among fishermen about access to the resource have resulted in political pressure on scientists to undertake research on the biology of bigeye scad around Reunion Island (Roux and Conand, 2000; Tessier et al., 2000). Surveys on the biology and ecology of this species have been carried out at many locations: Hawaii (Kawamoto, 1973 ; Clarke and Privitera, 1995), Granada Island (Finlay and Rennie, 1985), Java Sea (Sadhotomo and Atmadja, 1985), Cape Verde (Carvalho, 1986), the Philippines (Dy-Ali, 1988), Indonesia (Dazell and Peñaflor, 1989), Mozambique (Gislason and Sousa, 1984), the Seychelles (Ratcliffe, 1981), and the Aden Gulf (Podosinnikov, 1990).

The aim of this study was to determine, as precisely as possible, the main characteristics of the

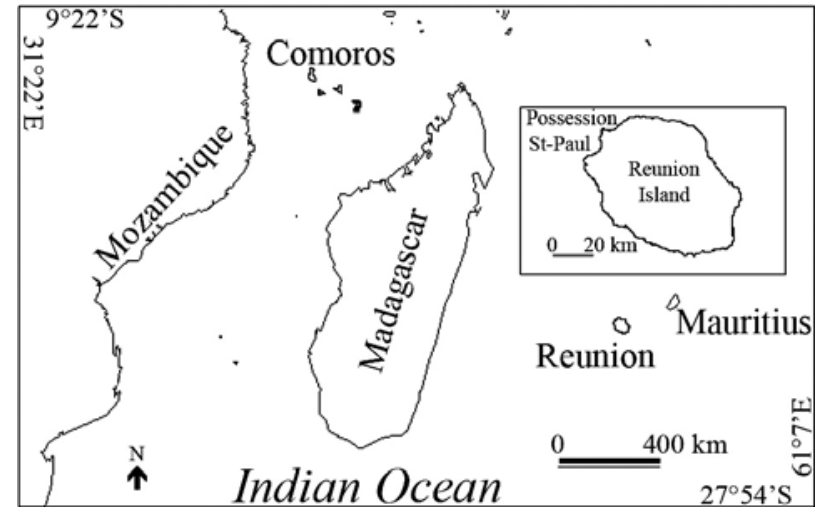

FIG. 1. - Location of Reunion Island in the southwest Indian Ocean.

biology of the bigeye scad, such as recruitment, growth and reproduction, for possible use in the management of the fisheries and for comparison with available data on this species and other carangids.

\section{MATERIAL AND METHODS}

Sampling from seine and handline commercial catches was carried out between August 1993 and October 1994. Field sampling for growth studies was conducted twice a month. At the St Paul and La Possession sites both beach-seine and handline techniques were used according to the moon phase and the availability of fish.

On a total of 1104 fish, several measurements (to the nearest $\mathrm{mm}$ for length and to the nearest gram for the weight) were recorded to set biometrical relations: total length $\left(\mathrm{T}_{\mathrm{L}}\right)$, fork length $\left(\mathrm{F}_{\mathrm{L}}\right)$, standard length $\left(\mathrm{S}_{\mathrm{L}}\right)$, height $(\mathrm{H})$ at the operculum level and weight $(\mathrm{W})$. Fork length, the most widely accepted standard (Ricker, 1980), was used for biological studies.

To study growth, 100 individuals were measured in the field at each fishing sampling, or the entire catches if fewer than 100 fish were caught. In the whole period, 2461 fishes were sampled. Growth parameter estimations were made using ELEFAN software (Pauly and David, 1981), which adjusts a von Bertalanffy curve to a frequency distribution classed by month, without taking the year into account, which is repeated sequentially so that a curve can be drawn. For species with a lifespan greater than 1 year, a seasonal modulation is observed (Pauly and Gaschutz, 1979). Then, the von Bertalanffy function is written as: 


$$
T_{L}=\mathrm{L}_{\infty}\left[1-\mathrm{e}\left(-\mathrm{K}\left(\mathrm{t}-\mathrm{t}_{0}\right)-\mathrm{C} \sin (\omega \mathrm{t}+\varphi)\right)\right]
$$

where $\mathrm{C}$ represents the amplitude of the seasonal modulation, $\omega$ is the pulsation of the modulation (equal to $2 \pi$, if the age is in years and the angle is in radiant), $K$ is the rate at which $L_{\infty}$ is approached and $\varphi$ is the modulation phase. $t_{0}$ is not calculated by ELEFAN. For the species with a $\mathrm{K}$ greater than $0.5, t_{0}$ is considered equal to zero. The sample included catches from two different fishing gears, beach-seines and handlines. The fishing method did not influence significantly the monthly length frequency distribution (Wilcoxon rank test: $\mathrm{p}>0.05$ ). Fishermen adjusted the size of hook and their wide mesh net sheets according to the size of fishes. The size distribution in the catches by hook and beach-seine were comparable.

Growth performance index $\phi$ (Munro and Pauly, 1983; Pauly and Munro, 1984) was calculated as:

$$
\phi=\log K+2 \log L_{\infty}
$$

The index so obtained was used for the comparisons with those of other stocks.

For the study of reproduction, a representative sample of 40 individuals was randomly chosen from the catches for immediate analysis in the laboratory. The total weight $\left(\mathrm{T}_{\mathrm{w}}\right)$, sex (male, female or undetermined), weight of gonads $\left(\mathrm{W}_{\mathrm{G}}\right)$ and sexual maturity stage were recorded to determine the spawning periods. Two types of data were used:

- Monthly variations of the sexual stages.

- Evolutions of the monthly averages of the gonad index (GI).

For the determination of the sexual stages, we employed the scale of maturity of Fontana (1969) based on the study of sardinella in the Congo. This scale includes seven stages: stages I and II (sexual idle period), stage III (in maturation), stage IV (prespawning), stage V (spawning), stage VI (postspawning) and stage VII (end of the last spawning and involution of the ovary). However, in this study, we did not consider stages VI and VII because they were rare and not easily differentiable. Males have flat knife-blade shaped testicles, whereas female ovaries are long and cylindrical. Classification was made with the naked eye, and only the well-developed and clearly identifiable gonads were kept. The sex-ratio evaluation does not take into account individuals whose sex could not be determined.

For the sex-ratio $\left(S_{R}\right)$ evaluation, the following ratio was used $(\mathrm{M}=$ number of males, $\mathrm{F}=$ number of females, $\mathrm{M}+\mathrm{F}=$ total number of individuals):

$$
S_{R}=\frac{M}{M+F} \times 100
$$

The gonad index was defined by the following relation:

$$
G I=\frac{W_{G}}{T_{W}} \times 100
$$

This was calculated for each individual and a monthly average was established for each sex.

First sexual maturity was defined for fish with a sexual maturity of stage IV at least. The average number of individuals (in percent) was calculated for each length class. The bigeye scad is considered mature as soon as $50 \%$ of the cohort have reached this stage (L50).

Non-parametric Wilcoxon tests were used to determine differences between males and females.

\section{RESULTS}

Commercial catches of Selar crumenophthalmus are estimated from the declarations of fishermen to the local marine administration (Direction Régionale des Affaires Maritimes (DRAM)). These catches, by both seine and handline, are seasonal and their level varied year by year (Fig. 2). Catches generally begin in March, when yields start to become attractive to fishermen, who can catch several metric tons by beach-seine operation and from 40 to 80 kilograms per handline per fisherman per day. These yields stay high until November, with higher catches in the period from March to October, when bigeye scad reach their maximum size (Fig. $3)$. The catches are easier when the fish are aggregating in shoals near the coastline.

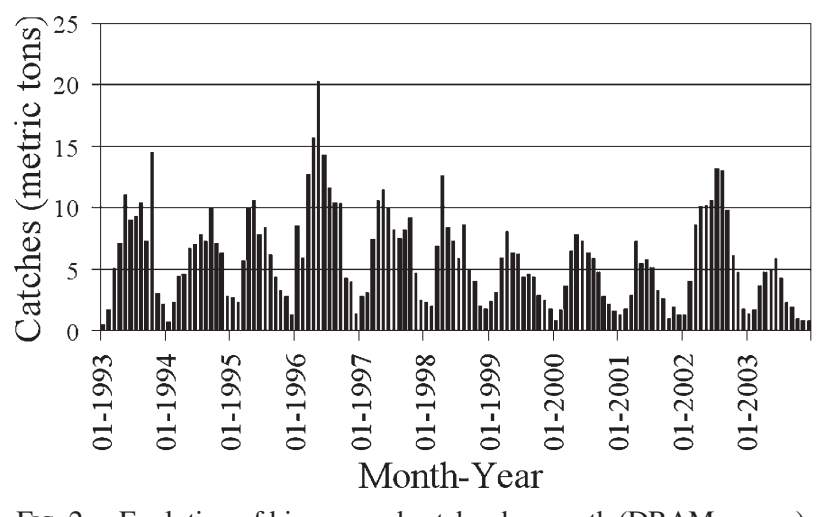

FIG. 2. - Evolution of bigeye scad catches by month (DRAM source). 


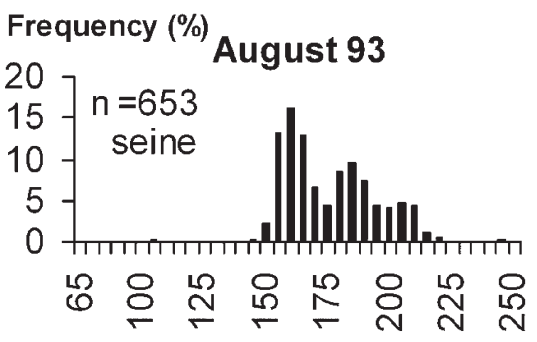

September 93

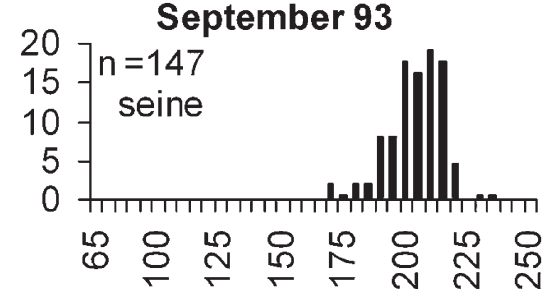

October 93

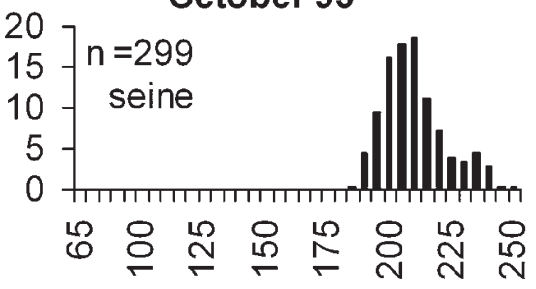

November 93
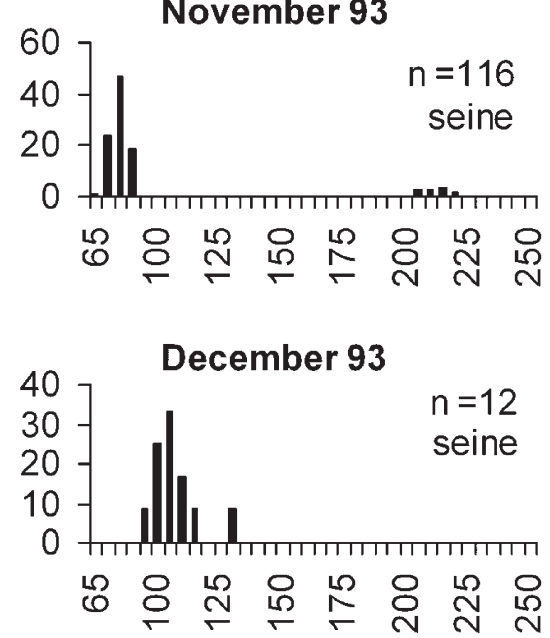
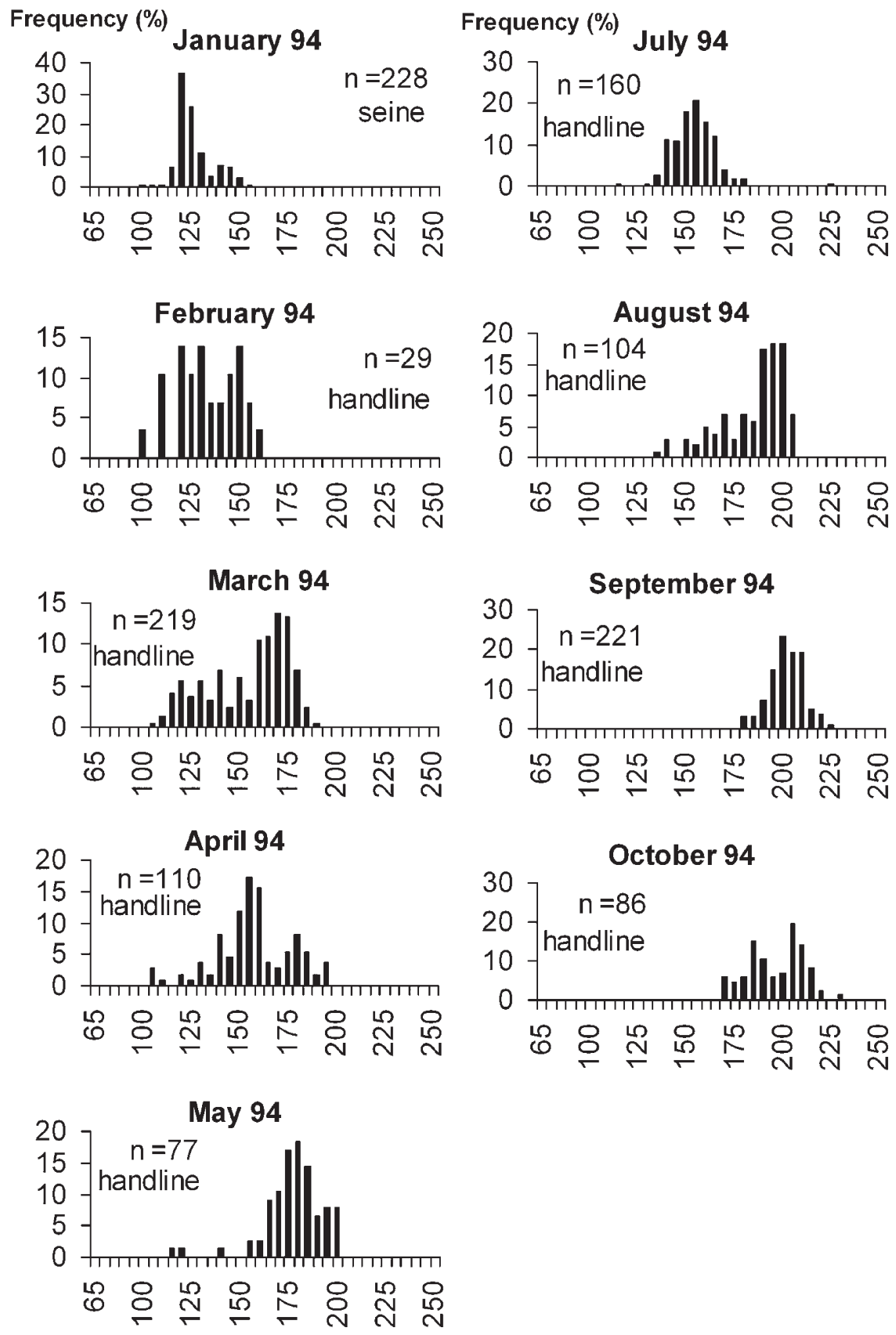

FIG. 3. - Monthly variation of size frequency distributions $\left(\mathrm{F}_{\mathrm{L}}\right)$.

Fishing for use as bait is practised all year long using only handlines, the hook size varying according to the season and the size of fish.

\section{Biometrics relationships}

Biometric relationships between fork length $\left(F_{L}\right)$ and total length $\left(T_{L}\right)$, standard length $\left(S_{L}\right)$ and height $(H)$ were calculated on 728 individuals, whose fork length varied from 65 to $250 \mathrm{~mm}$. Simple linear regressions $\left(\hat{y}=b_{0}+b_{1} x\right)$ were used to fit the relations. Parameters of the equation with a standard error (Se) and the statistical $\mathrm{F}$ value are given in Table 1 for each length.

\section{Length/Weight relations}

Parameters of the equation $W=a F_{L}{ }^{n}$ are given in Table 2 for males, females, undetermined and a balanced sample with all fishes. 
TABLE 1. - Biometric relationships parameters between fork length $\left(F_{L}\right)$ and three other lengths (in $\mathrm{mm}$ ).

\begin{tabular}{lcccccc}
\hline & $\mathrm{b}_{0}$ & Se $\mathrm{b}_{0}$ & $\mathrm{~b}_{1}$ & $\mathrm{Se}_{1}$ & $\mathrm{R}^{2}$ & $\mathrm{~F}$ observed \\
\hline Total length & -3.999 & 0.259 & 1.1538 & 0.001 & 0.998 & 725 \\
Standard length & -1.446 & 0.226 & 0.971 & 0.001 & 0.998 & 725 \\
Height & -4.289 & 0.244 & 0.2635 & 0.001 & 570741.1 & 725 \\
\hline
\end{tabular}

TABLE 2. - Length/weight relation, weight in grams, fork length in $\mathrm{mm} ; N$, size of the sample; Lmin and Lmax are respectively minimum and maximum observed sizes.

\begin{tabular}{|c|c|c|c|c|c|c|}
\hline & $\mathrm{N}$ & $F_{\text {Lmin }}$ & $F_{\text {Lmax }}$ & $\mathrm{R}^{2}$ & $a$ & $\mathrm{n}$ \\
\hline Male & 318 & 139 & 255 & 0.9568 & $510^{-6}$ & 3.2247 \\
\hline Female & 374 & 136 & 237 & 0.9662 & $210^{-6}$ & 3.3695 \\
\hline Undetermined & 412 & 67 & 200 & 0.986 & $410^{-6}$ & 3.2431 \\
\hline Total whole & 1104 & 67 & 255 & 0.9911 & $410^{-6}$ & 3.2593 \\
\hline
\end{tabular}

\section{Growth}

Growth studies were conducted by monitoring size distribution in the population, but sampling was not as regular as initially scheduled, mainly due to unfavourable weather conditions. In the following results, the observed size distributions were aggregated by month, in order to obtain a regular time period and a large sample of the population.

Figure 3 presents size frequency histograms, calculated from seine and handline fishing samples. The samples showed single, bimodal or increasing modes (July 1994) in the structure of the stock. In August 1993, the development of one sampling cohort composed of quite large individuals (between 130 and $200 \mathrm{~mm} \mathrm{~F}_{\mathrm{L}}$ ) was monitored until November, when it completely disappeared from

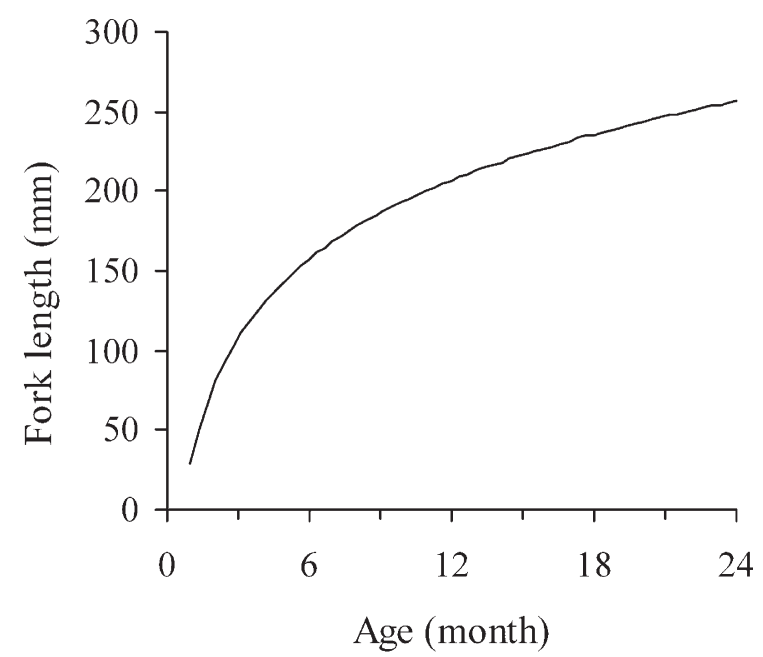

FIG. 4. - Bigeye scad von Bertalanffy adjusted growth curve, calculated with parameter estimations using ELEFAN software. our samples. At the same time, a new cohort composed of homogeneous small size individuals (between 65 and $90 \mathrm{~mm} \mathrm{~F}_{\mathrm{L}}$ ) appeared and grew progressively in subsequent months.

Growth parameters estimations were conducted using ELEFAN software. The estimates of best fit are $\mathrm{K}=1.64, \mathrm{~L}_{\infty}=265 \mathrm{~mm}, \mathrm{c}=0.068$ and $\varphi=0.38$, where length is expressed in $\mathrm{mm}$ and age in years.

This equation can be used to develop a theoretical growth curve. The following size-age relationships are then obtained: 3 months $-105 \mathrm{~mm}, 6$ months $-142 \mathrm{~mm}$ and 12 months $-220 \mathrm{~mm}$. This confirms the hypothesis that rapid growth is a characteristic of bigeye scad (Fig. 4).

Growth performance index $(\phi)$ was 3.06.

\section{Reproduction}

The sex-ratio was globally balanced (female $=54 \%$, male $=46 \% ; \mathrm{W}=4390, \mathrm{P}=0.2079$ ). The average size of the male and the female did not differ significantly ( $\mathrm{W}=56198.5, \mathrm{P}=0.2123$ ). The monthly distribution for male, female and undetermined individuals (Fig. 5) showed that recruitment of juveniles (undetermined) occurs in the fishery in November and that they progressively achieve adulthood from December to February, then gradually disappear by August. A few maturing individuals appear in April. Then the proportion of mature

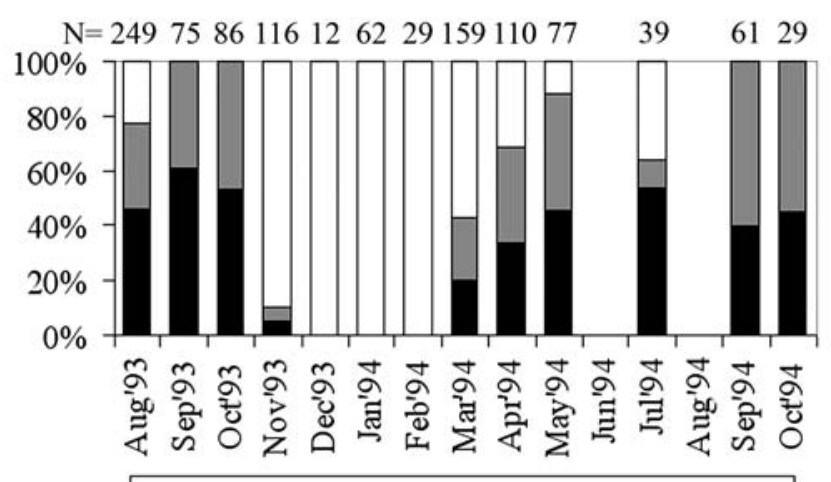

- Female $\square$ Male $\square$ Undetermined

FIG. 5. - Monthly distribution of sexes. 

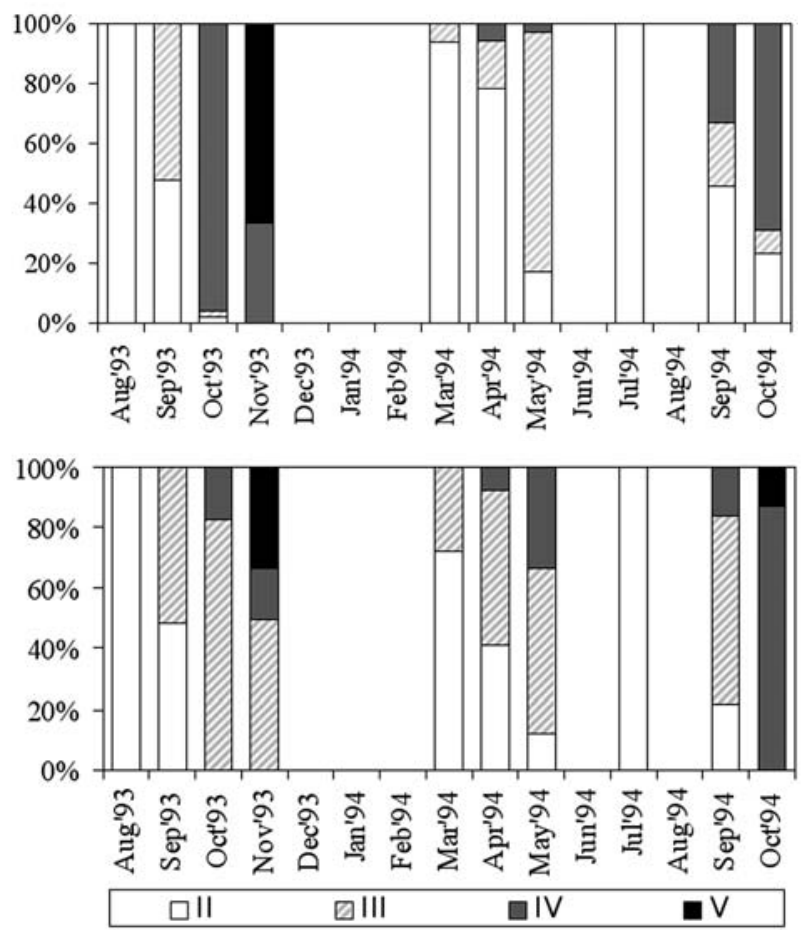

FIG. 6. - Evolution of gonad maturity in females (a) and males (b).

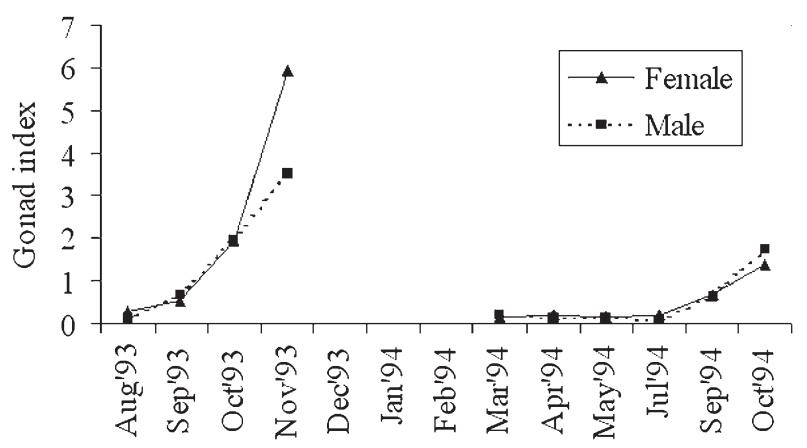

FIG. 7. - Gonad index variations.

fish progressively increases until October. Spawning was observed in November (Fig. 6a and Fig. 6b). No significant difference in the maturation stage was observed between male and female. The variation of the gonad index (Fig. 7) corroborates the observations on maturity stages. The size at first maturity (L50) was reached at $215 \mathrm{~mm}$ (Fig. 8).

\section{DISCUSSION}

Around Reunion Island, the bigeye scad is a small coastal pelagic fish reaching $255 \mathrm{~mm}$ mean fork length which achieves sexual maturity at $215 \mathrm{~mm}$. The fitted model of growth gives a size of $105 \mathrm{~mm}$ at 3 months, $142 \mathrm{~mm}$ at 6 months and $220 \mathrm{~mm}$ at 1 year.

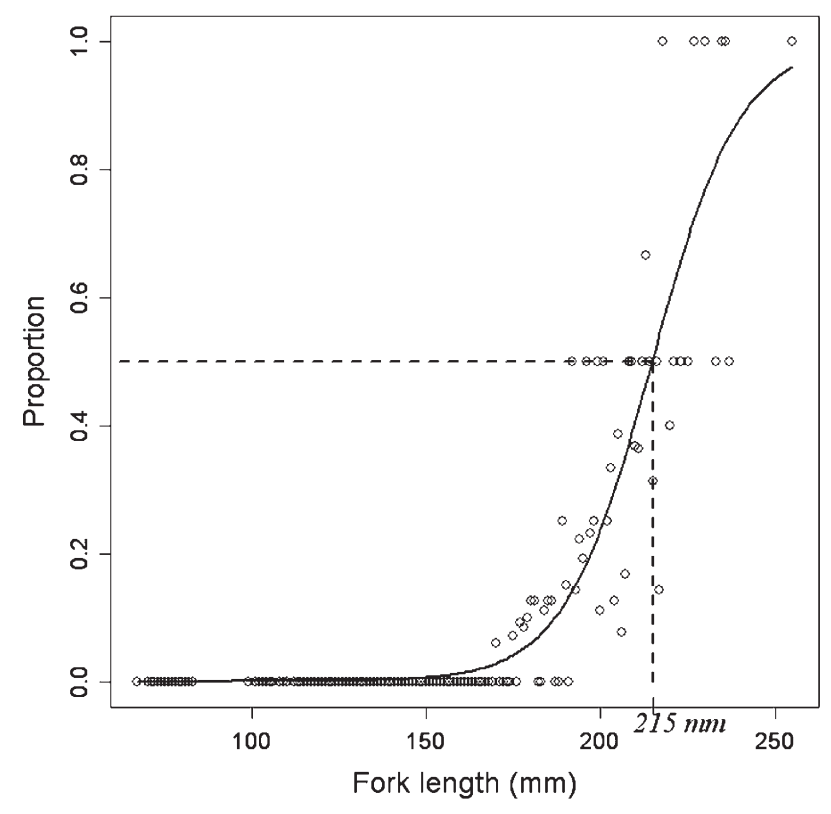

FIG. 8. - The logistic relationships between the number of reproductive bigeye scad (expressed as a proportion of sexually mature specimens) and fork length.

It is interesting to compare with results from other studies (Table 3). For 3-month-old individuals, the difference between the size recorded by Carvalho $(75 \mathrm{~mm})$ and that observed around Reunion $(105 \mathrm{~mm})$ may be explained by the growth function variations fitted to a sinusoidal modulation. García and Duarte (2006) showed that growth parameter estimation is not systematically comparable for the different stock of bigeye scad. The comparison of $19 \phi$ values found in Fishbase (http://www.fishbase.org) by these authors for this species were in agreement with our result (range $=$ 2.78-3.24; 95\% confidence intervals=2.93-3.08), but not with theirs. They suggested that this difference could be attributable to genuine geographic variation.

Regarding the size frequency distributions $\left(\mathrm{F}_{\mathrm{L}}\right)$, the cohort appearing in November (Fig. 3) was characterised by the arrival of juveniles in the fishery;

TABLE 3. - Comparison of age/length $\left(\mathrm{F}_{\mathrm{L}}\right)$ data obtained by other authors in different countries

\begin{tabular}{lccc}
\hline & 3 months & 6 months & 12 months \\
\hline $\begin{array}{l}\text { Carvalho (1986) } \\
\text { (Cape Verde) }\end{array}$ & $75 \mathrm{~mm}$ & $140 \mathrm{~mm}$ & $215 \mathrm{~mm}$ \\
$\begin{array}{l}\text { Dalzell and Penaflor (1989) } \\
\text { (Philippines) }\end{array}$ & - & $130 \mathrm{~mm}$ & $230 \mathrm{~mm}$ \\
$\begin{array}{l}\text { Results of the survey } \\
\text { (Reunion Island) }\end{array}$ & $105 \mathrm{~mm}$ & $142 \mathrm{~mm}$ & $220 \mathrm{~mm}$ \\
\hline
\end{tabular}


they may be coming from another site, or their size might then catchable using local fishing techniques. The growth of the cohort is rapid: fish attain 170 to $190 \mathrm{~mm}$ fork length in April. From that time growth slows down, with fish reaching 170 to $215 \mathrm{~mm}$ in October. This decline in the growth rate could be due to the decrease in temperature during the austral winter, which is quite marked on Reunion (Conand et al., 2005), and/or to physiological condition on reaching maturity (energetic cost). This cohort then disappears in December, either because of natural mortality of the fish or because of migrations out of the area accessible to fishermen.

The study of the reproductive cycle showed spawning fish in November, although the first records of fish reaching sexual maturity appeared in April. The staggering of the reproductive season could explain the bimodal structure or change observed in the monthly survey (Fig. 3). If the first recruitment of juveniles between 70 and $90 \mathrm{~mm}$, whose age could be from 1 to 2 months, appears during November in the commercial catches, it is likely that some fish start spawning in August or September. For several years observations by scuba diving scientists near the coast have described bigeye scad juvenile recruitment from August (Taquet M., pers. comm.). In August, bigeye scad juveniles cannot be caught by handline or beach-seine, which are designed for adults shoaling in large numbers. Two hypotheses could explain this phenomenon:

Spawning periods could be staggered from April to November, with a peak from September to November (Fig. 6a, 6b, Fig. 7 and Fig. 8). Figure 6a shows that, from April and May, only 3 to $7 \%$ of females have reached stage IV of maturity. This would suggest that there are different cohorts, with different maturity stages and a spawning probability from April-May, although the majority of the population is in an immature phase. Larger and more regular samples during this time (June to September) could have provided data to better support these conclusions.

With regard to the sites, as soon as the cohorts begin to spawn, larvae and post-larvae would have been displaced by coastal currents to other more distant sites. Simultaneously, larvae from the fishery could be carried away, which could explain why no sample would support possible spawning in November. This might explain the earlier appearance of mature individuals in 1994 in La Possession Bay, whereas samples of early maturing individuals in 1993 came from Saint-Paul Bay, some $30 \mathrm{~km}$ away. The apparent delay could be due to this spatial gap. However, this hypothesis is unlikely.

Several studies have shown that bigeye scad reproduction extends over a period of 6 to 7 months: between March and September (Tobias, 1987) or April and September (Kawamoto, 1973 ; Clarke and Privitera, 1995). Further spawning extending over 3 days has been observed for bigeye scad (Clarke and Privitera, 1995). All these observations occurred in the northern hemisphere. With a sixmonth delay in the southern hemisphere, this could correspond to the beginning of spawning around August and September.

After a survey carried out by fishermen and the analysis of size progression, it appears that from November a disappearance of large, one-year-old individuals occurs in the fishery. Several hypotheses have been proposed. According to Dalzell and Peñaflor (1989), this phenomena could be due to a migration to open sea and deeper waters. Johannes (1981) thinks that this could allow the fish to recover their body mass. Finlay and Rennie (1985) conclude that in Granada this phenomenon is closely linked to the arrival of other large pelagic species along the coastline, which would make small pelagics emigrate to areas less accessible to fishermen. A final hypothesis suggests that the disappearance of adults is attributable to massive mortality due to physiological stress after reproduction. Kawamoto (1973) estimated that annual survival of bigeye scad was then $0.7 \%$, and annual mortality $99.3 \%$. According to our observation, bigeye scad seem to die in large numbers after their first reproduction season. Other studies on other small pelagic fishes reach the same conclusion. Williams and Clarke (1983), Lewis et al. (1983), and Anon (1983) point out that the gold spot herring (Herklotsichthys quadrimaculatus) does not survive long after reproduction. Conand (1991), in a study on sardinella (Amblygaster syrm), demonstrated that this species shows an obvious trend towards semelparity. After a single 2- to 3-month reproductive season, during which they spawn several times, most of the adults die.

This study provides the first description of bigeye scad reproduction and growth around Reunion Island. The life cycle of this species is rapid and of short duration and suggests that after reproduction massive mortality occurs and few individuals survive. Also, as this study is based on samples from fishery catches, data biased by the fishing technique 
(e.g. selectivity of engines, season, catch effort) could have been generated. These biases limit the certainty of our understanding of the dynamics of bigeye scad. To improve on these preliminary results, we intend to use acoustic sampling methods, which appear to be a promising and useful tool to observe and study aquatic ecosystems and to evaluate fishery resources. This method provides information not only on the identity, abundance and distribution of aquatic species, but also on their size and behaviour (Soria, 1994; Horne, 2000). Age parameters will also be obtained from a study of sagittal otoliths, in order to confirm the preliminary results.

\section{ACKNOWLEDGEMENTS}

We thank Mr. Jean René Enilorac and all the fishermen who supported the research by permitting us to collect samples from their catches. We thank Prof. George Hughes, Prof. Chantal Conand and Dr. Fréderic Ménard for helpful comments and suggestions.

\section{REFERENCES}

Anon. - 1983. L'appât vivant aux Seychelles: synthèse des connaissances acquises. Rapp. Sci. Mission ORSTOM Seychelles, 1: $68 \mathrm{pp}$.

Biais, G. and M. Taquet. - 1992. La pêche locale aux abords de La Réunion. Repères océan, 2: 78 pp.

Carvalho, M.E. - 1986. Contribution à l'étude de quelques petits pélagiques du Cap-Vert. Rapport du $2^{\text {ème }}$ groupe de travail ad hoc sur les chinchards et les maquereaux de la zone nord du Copace. FAO Fish. Report: 143-172.

Clarke, T.A. and L.A. Privitera. - 1995. Reproductive biology of two Hawaiian pelagic carangid fishes, the Bigeye scad, Selar crumenophthalmus, and the round scad, Decapterus macarellus. Bull. Mar. Sci., 56(1): 33-47.

Conand, F. - 1991. Biology and phenology of Amblygaster sirm (Clupeidae) in New Caledonia, a sardine of the coral environment. Bull. Mar. Sci., 48(1): 137-149.

Conand, F., F. Marsac, E. Tessier and C. Conand. - 2005. Ten years of daily sea subsurface temperature at a coastal station in Reunion Island, Indian Ocean (July 1993-March 2004). $4^{\text {th }}$ WIOMSA Symp. Book of Abstracts.

Dalzell, P. and G. Peñaflor. - 1989. The fisheries biology of the bigeye scad Selar crumenophthalmus (Bloch) in the Philippines. Asian Fish. Sci., (3): 115-131.

Dy-ali, E. - 1988. Growth, mortality, recruitment and exploitation rate of Selar boops in Davao Gulf, Philippines. Contribution to tropical fisheries biology. FAO Fish. Rep., 389: 346-355.

Finlay, J. and J. Rennie. - 1985. Variability in abundance of small inshore pelagics on the Island of Grenada. FAO Fish. Rep., 327: 183-193.
Fontana, A. - 1969. Etude de la maturité sexuelle des sardinelles Sardinella eba et $S$. aurita de la région de la Pointe Noire. Cahiers ORSTOM, Série Océanographique, 7(2): 101-104

Garcia, C.B. and L.O. Duarte. - 2006. Length-based estimates of growth parameters and mortality rates of fish populations of the Caribbean Sea. J. Appl. Ichthyol., 22: 193-200.

Gislason, H. and M.I. Sousa. - 1989. Results of a stratified random bottom trawl survey for scad and mackerel in Mozambican waters, from may to June 1984. Rev. Invest. Pesq., 19: 1-54.

Horne, J.K. - 2000. Acoustic approaches to remote species identification : a review. Fish. Oceanogr., 9 (4): 356-371.

Johannes, R.E. - 1981. Words of the lagoon. Fishing and marine lore in the Palau district of Micronesia. Univ. California Press.

Kawamoto, P.Y - 1973. Management investigation of the akule or bigeye scad Trachurops crumenophthalmus (Bloch). Hawaii Dept. of Fish and Game, Project Report H-4-r, Honolulu.

Lewis, A.D., S. Sharma, J. Prakash and B. Tikomainiusiladi. 1983. The Fiji baitfishery 1981-82, with notes on the biology of the gold spot herring, Herklotsichthys quadrimaculatus (Clupeidae), and the blue sprat, Spratelloides delicatulus (Dussumeiriidae). Fisheries Division, M.A.F., Suva, Fiji, Technical Report (6).

Munro, J.L. and D. Pauly. - 1983. A simple method for comparing the growth of fishes and invertebrates. Fishbyte, 1: 5-6

Pauly, D. and G. Gaschutz. - 1979. A simple method for fitting oscillating length growth data, with a program for pocket calculators. CIEM CM 1979/G:24 Demersal Fish Ctte: 26 pp.

Pauly, D. and N. David. - 1981. ELEFAN I, a BASIC programme for the objective extraction of growth parameters from length frequency data. Meeresforschung, 28(4): 205-211.

Pauly, D. and J.L. Munro. - 1984. Once more on growth comparison in fish and invertebrates. Fishbyte, 2: 21 p.

Podosinnikov, A.Y. - 1990. Information on the development of scads in the Gulf of Aden. Vopr. Ihtiol., 30(4): 688-692.

Ratcliffe, C. - 1981. Purse seine trials of Mahe (Seychelles) for small pelagic fish, 1973. Fish. Bull. Fish. Div.: 9 pp.

Roos, D., E. Tessier and D. Guyomard. - 1998. Evolution de l'activité halieutique à La Réunion de 1990-1996. Rapp. Sci. Tech. Ifremer, DRV/RH/RST/98-14: $67 \mathrm{pp}$.

Roos, D., E. Tessier, P. Berthier and L. Berthier. - 2000. Les métiers de la pêche à La Réunion: description et évolution des techniques de pêche sur les DCP. In: J.Y. Le Gall, P. Cayré and M. Taquet (eds.), Pêche thonière et dispositifs de concentration de poissons, 28: 333-345.

Roux, O. and F. Conand. - 2000. Feeding habits of the Bigeye scad, Selar crumenophthalmus (Carangidae), in La Reunion Island waters (South-Western Indian Ocean). Cybium, 24(2): 173-179.

Sadhotomo, B. and D.B. Atmadja. - 1985. On the growth of small pelagic fishes in the Java Sea. J. Pen. Perikanan Laut., 33: 53-60.

Soria, M. - 1994. Structure et stabilité des bancs et agrégations de poissons pélagiques côtiers tropicaux: application halieutique. Ph.D. thesis, Univ. Rennes.

Tessier, E., H. Rey-Valette, D. Ah-Nième, R.M. Bargain, A. Venkatasamy and B. Wendling. - 2000. Systèmes halieutiques et DCP dans l'océan Indien: une revue de la diversité des expériences et des résultats en termes d'intégration et de durabilité. In: J.Y. Le Gall, P. Cayré and M. Taquet (eds.), Pêche thonière et dispositifs de concentration de poissons, 28: 159-183.

Tobias, W. - 1987. Resource evaluation of the Bigeye scad Selar crumenophthalmus in the insular shelf waters around St. Croix, US Virgin Islands. Proc. Gulf Carrib. Fish. Inst., 40: 82-98.

Williams, V.R. and T.A. Clarke. - 1983. Reproduction, growth, and other aspect of the biology of the gold spot herring, Herklotsichthys quadrimaculatus (Clupeidae), a recent introduction to Hawaii. Fish. Bull., 81 (3): 587-597.

Scient. ed.: I. Palomera

Received March 13, 2006. Accepted November 20, 2006.

Published online February 26, 2007. 